\title{
SYSTEMIC BEHAVIOR VIA SOCIAL RESPONSIBILITY AS A WAY TO PEACE AND DEVELOPMENT ${ }^{1}$
}

\author{
Author(s) / Auteur(s) : \\ Emer. Prof. Dr., Dr. Matjaž MULEJ \\ Institute for development of social responsibility (IRDO) \\ University of Maribor, Slovenia \\ Faculty of Economics and Business, Maribor, Slovenia \\ International Academy for Systems and Cybernetic Sciences (IASCYS) \\ mulej@uni-mb.si matjaz.mulej@um.si
}

\begin{abstract}
Résumé :
Systemic behavior is here to overcome the ancient human one-sided and short-term behavior by holistic approach based on interdependence of cooperating professionals, who are mutually different. The new way toward this end was passed only two years after the surfacing of the current global socio-economic crisis that results from neoliberal monopolies. Social responsibility is everyone's (new) responsibility for his/her influence on society on the basis of practicing interdependence as a precondition for requisite holism. Consequences of millennia of the human practice of one-sidedness and short-term criteria of behavior make social responsibility now unavoidable: the $3^{\text {rd }}$ World War is here/pending rather than peace and development. Both interdependence and (requisite) holism are exposed by both systems theory and ISO 26000 on social responsibility. The unfortunate and dangerous - situation in society is well clarified by the fact that ISO 26000 was passed only as an advisory rather than obligatory international standard; this means that peace is considered less important than companies' profit, while peace is a crucial precondition for profit/benefit resulting from development and well-being.
\end{abstract}

\section{Keywords / Mots-clés :}

social responsibility, world peace, international cooperation

\section{THE SELECTED PROBLEM AND VIEWPOINT}

Many data in daily media show that the current humanity is far from peace and development. Obviously, humans/organizations with the strongest impact on the world-wide life reality often prefer their own short-term and narrow-mindedly defined profits/benefits over the general human well-being. This global and very dangerous fact may be seen as a complex crucial reason for United Nations, European Union, associations of progressive companies, International Standards Organization (ISO) to pass their documents on social responsibility and consider social responsibility the way out from the current socio-economic crises. Many persons ask 'What do I have to do with social responsibility? What and how can I contribute? How can I benefit?' We wish to help them in this overview of the essence of social responsibility and add our eight recent books and three guest-edited journals and ten conference proceedings, generated (under my chairing and co-editing) in volunteering international cooperation, based on research by International Academy of Systems and Cybernetic Sciences (IASCYS) and the 'Scientific research center of IRDO', and the University of Maribor, Faculty of Economics and Business. We have no room here for details about the further IRDO commissioned research projects, which have also been crucial.

\footnotetext{
${ }^{1}$ For the IASCYS workshop "Systemic means holistic, beyond the local and short-term criteria of benefit" during the $10^{\text {th }}$ Congress of European Union for Systemics in Brussels, 15-17 of October 2018.
} 


\section{THE ESSENCE OF SOCIAL RESPONSIBILITY - HUMAN VALUES FOR END OF NEOLIBERALISM AND WAR}

Social responsibility is deeply rooted in human attributes that are expressed with the seven principles in ISO 26000 (ISO, 2010):

1. Accountability

2. Transparency

3. Ethical behavior

4. Respect for stakeholders

5. Respect for rule of law

6. Respect for international norms

7. Respect for human rights

And in two concepts from systems theory:

a) Interdependence

b) Holistic approach.

See Figure 1.

\section{Social responsibility:

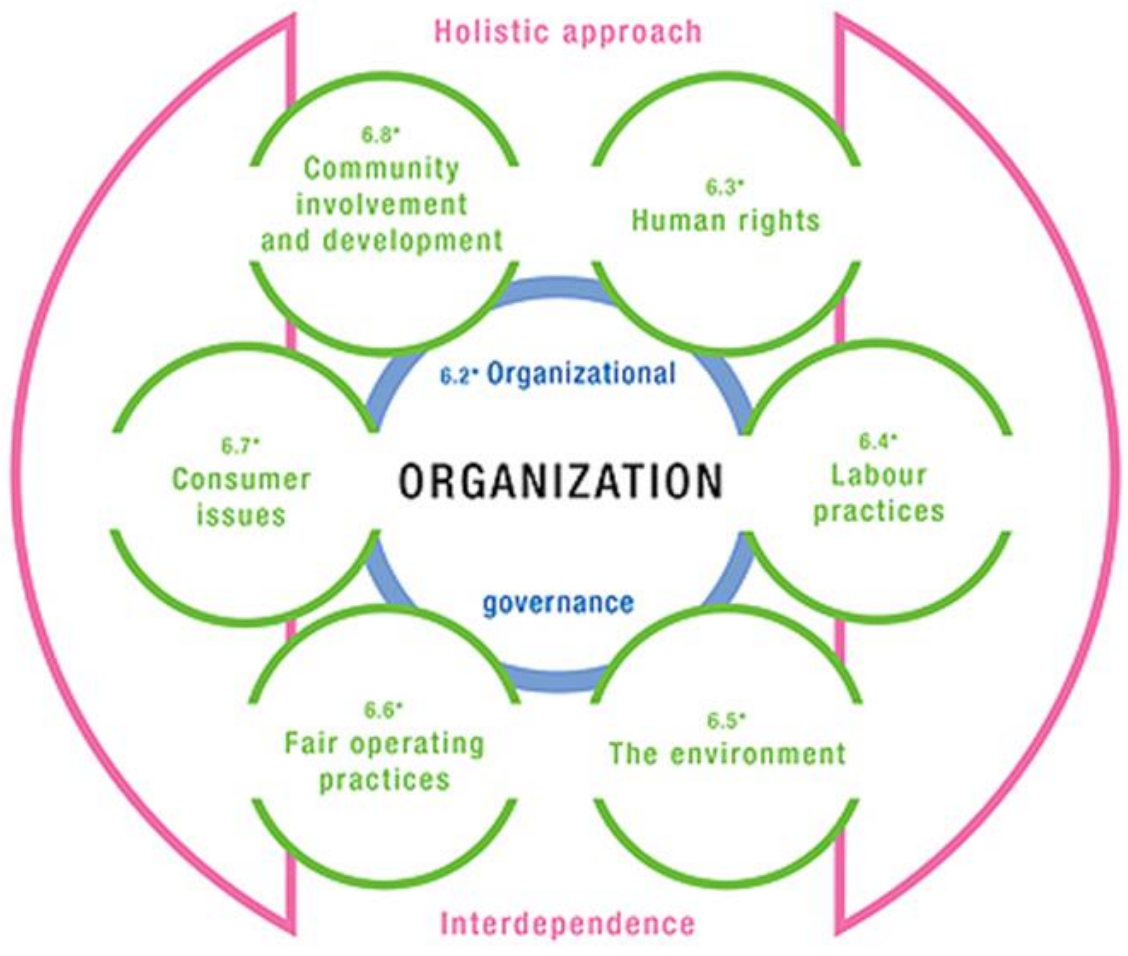

- The figures denote the corresponding clause numbers in $1 \$ 026000$.

Figure 1: The seven core subjects and two crucial linking concepts: Interdependence and holistic approach, of social responsibility in ISO 26000 
The neo-liberal economic practice of the entire period after the Second World War disables social responsibility, while it does not impact governance of enterprises only, but all organizations and humans. Finally, many around the world find neoliberalism obsolete now: it causes prevailing of onesidedness over organizational individual and political holistic decision-making and action, with very dangerous consequences, such as the current global social, economic, and environmental crisis, resulting from forgetting about interdependence as a crucial part of global economy and society. Market is no longer free, but monopolized.

Neoliberalism cannot solve the consequences of its monopolism, because it has caused them. The oldmain-stream economists offer no new solutions, while experts in some of the systems and cybernetic theories, United Nations, European Union, and more recently the International Standard Organization (ISO) do, although on the level of basic principles, so far.

Market alone has not proved to be able to rebalance crucial consequences of human one-sidedness, neither have governments alone; both are too monopolized to attain requisite holism, which humanity needs to survive: (1) eighty percent of the global market are controlled by less than 750 out of the studied thirty million organizations; (2) nobody can become president, e.g. in USA without money from big companies that pursue their interests rather than the human and humane ones. (For details see e.g. Mulej, Dyck, ed., 2014, and other references added).

Systems theory and cybernetics have offered holism of approach for wholeness of outcomes (i.e. no crucial oversights and over-specialization) for close to seven decades; now United Nations, European Union and ISO offer it with their new concept of social responsibility (SR) (ISO 2010; EU 2011).

The essence of democracy that is supposed to solve the current global peace problems, is not the mutual replacement of political parties in power, but the highest possible level of holism in decision making and taking beyond outvoting. The representative type of democracy organizing cannot be overcome yet (Grün, Zeitz, 2012). But the process in the elected bodies can be made more holistic in its approach and lead to more wholeness in its outcomes, e.g. with methods such as USOMID and 'Six Thinking Hats' (see: Mulej et al., 2013). They resulted from the terrible experiences with onesidedness and its global impact in the $20^{\text {th }}$ century.

In the $20^{\text {th }}$ century the world, and especially Europe, went through a triple terrible crisis: two World Wars and Big depression between them, in 1914-1945. Details have no room here, but a few facts do. (1) The crisis resulted from one-sidedness of the influential persons and their organizations, both governments/countries and enterprises. (2) The one-sided demand in the peace treaty after the First World War demanded Germany to repay huge war reparations with no export led to the WWII. (3) The one-sided decision of Hitler's $3^{\text {rd }}$ Reich to open several war fronts helped the more holistic Allies to win the WWII. (4) The Keynesian model of finishing the crisis looked quite holistic, but Hitler's usage of similar methods of public works etc. finished unemployment by war, which was a very onesided and terrible practice. (5) Democracy in politics was/is one-sided out-voting and hence did/does not prevent troubles. Etc.

The short-term and narrow-minded behavior is typical of the neo-liberal economics; it can no longer work. Under the label of the free market it made monopolies ruin the free market and social control over big enterprises. Thus, it caused a crisis that differs from all crises of so far - crisis of affluence with 'skyscrapers built on debts rather than on solid rock'. In affluence the real human needs and ambitions are covered, greed and shopping-addiction no longer create enough demand for suppliers to find consumers, and human ambitions address well-being and SR beyond ownership of goods; consumers create jobs and well-being, not investors.

The crises require solutions. In previous periods and economic orders, there were many less people (the first billion, with only three percent of people living in towns, in times of Napoleon) e.g. the humans' natural environment was only a resource, for which the price was not fully charged to the businesses and other users; now it is an asset (clean water, air, soil), all way to wars for resources that may lead to the $3^{\text {rd }}$ world war globally.

Humankind's over-production changed the environment so drastically, that the so-far practice of nature's over-exploitation is very dangerous. Regarding e.g. the climate changes at least three aspects 
should be considered: direct impact of the changed climate on economy and world peace, adaptation of economy to changed climate, and remediation of the climate changes' consequences in due/real time. One-sidedness causes also these troubles. In human responses to crises, the natural and social environment and sustainability should be included. They depend on influential humans' behavior, hence on human thinking, values and knowledge. Their respect for systemic / holistic thinking/behavior and resulting synergies could create peace and development. Social responsibility (SR) supports it, although informally (ISO, 2010) by stressing that interdependence is the basis: Figure 1.

International Standard ISO 26000 is a great guidance to SR, actually to systemic behavior. We expect that as Kyoto protocol since 1990 has introduces many global changes, so will the ISO 26000. At the same time ISO 26000 is guidance, not an international law. Hence, it depends on influential humans practicing the above cited seven principles/values in all seven basic contents of life, included in Figure 1 , with interdependence as the basis.

With ethics of interdependence, the cooperation of many specialists and participants becomes possible and leads to requisite holism, thus making systemic SR acting achievable. So does mutual reliability, honesty, hence longer-term and more holistic criteria and practice of behavior, and similar human attributes making life and business better and cheaper via SR.

Obviously, an innovation of values is demanded. It should enjoy methodological support.

\section{A POTENTIAL METHODOLOGICAL SUPPORT FOR HUMAN TRANSITION FROM ONE-SIDED TO REQUISITELY HOLISTIC BEHAVIOR VIA SOCIAL RESPONSIBILITY}

Social responsibility adds to influential persons and organizations the values aimed at their doing more than the law requires officially, because this helps them do a better job than the others do, by more requisite holism of their approach and wholeness of their outcomes. Methodologically, combing the ' 6 Thinking hats and USOMID' as summarized in Tables 1 and 2 can help governors and managers run their region and organizations with requisite holism and hence successfully (See Mulej et al, 2013, for details and references).

- White = neutral, objective, facts without interpretation, like a computer;

- $\quad$ Red = feelings, emotions, intuition, irrationality, unproved feelings, no justification;

- $\quad$ Black = watching out, caution, pessimism, search for danger, doubt, critique; it all works well against mistakes and weak points of proposals;

- $\quad$ Yellow = optimism, search for advantages of proposals, search for implementation ways, sensitivity for benefit of the idea, constructive approach;

- Green = energy, novelty, creation, innovation, in order to be able to overcome all obstacles;

- $\quad$ Blue $=$ organization, mastering, control over procedure, thinking about thinking.

Table 1: Essence of each of the six thinking hats (applied in phases; all participants use the same hat at the same time in the same phase, and then switch to another hat all together) 


\begin{tabular}{|c|c|c|c|c|c|c|}
\hline $\begin{array}{l}\text { SREDIM Phases } \\
\text { USOMID } \\
\text { Steps } \\
\text { Inside } \\
\text { SREDIM } \\
\text { Phases }\end{array}$ & $\begin{array}{l}\text { 1. Select } \\
\text { problem / } \\
\text { opportunity } \\
\text { to work on } \\
\text { in an } \\
\text { USOMID } \\
\text { circle }\end{array}$ & $\begin{array}{l}\text { 2. Record } \\
\text { data } \\
\text { about the } \\
\text { selected } \\
\text { topic (no } \\
\text { 'Why') }\end{array}$ & $\begin{array}{l}\text { 3. Evaluate } \\
\text { recorded data } \\
\text { on the topic } \\
\text { ('Why is } \\
\text { central') }\end{array}$ & $\begin{array}{l}\text { 4. Determine } \\
\text { and develop } \\
\text { chosen } \\
\text { solution/s to } \\
\text { the topic }\end{array}$ & $\begin{array}{l}\text { 5. Imple- } \\
\text { ment chosen } \\
\text { solution to } \\
\text { the topic in } \\
\text { reality }\end{array}$ & $\begin{array}{l}\text { 6. Maintain } \\
\text { implemented } \\
\text { solution for } \\
\text { a requisitely } \\
\text { long term }\end{array}$ \\
\hline $\begin{array}{l}\text { 1. Individual } \\
\text { brain-writing by } \\
\text { all in the } \\
\text { organisational } \\
\text { unit / circle }\end{array}$ & All 6 hats & White hat & $\begin{array}{l}\text { All } 6 \text { hats, red, } \\
\text { black, yellow, } \\
\text { green first of } \\
\text { all }\end{array}$ & $\begin{array}{l}\text { All } 6 \text { hats, } \\
\text { red, black, } \\
\text { yellow, } \\
\text { green first of } \\
\text { all }\end{array}$ & $\begin{array}{l}\text { All } 6 \text { hats in } \\
\text { preparation } \\
\text { of imple- } \\
\text { mentation }\end{array}$ & $\begin{array}{l}\text { All } 6 \text { hats in } \\
\text { preparation } \\
\text { of mainte- } \\
\text { nance }\end{array}$ \\
\hline $\begin{array}{l}\text { 2. Circulation of } \\
\text { notes for ad- } \\
\text { ditional brain- } \\
\text { writing by all }\end{array}$ & All 6 hats & White hat & $\begin{array}{l}\text { All } 6 \text { hats, red, } \\
\text { black, yellow, } \\
\text { green first of } \\
\text { all }\end{array}$ & $\begin{array}{l}\text { All } 6 \text { hats, } \\
\text { red, black, } \\
\text { yellow, } \\
\text { green first of } \\
\text { all }\end{array}$ & $\begin{array}{l}\text { All } 6 \text { hats in } \\
\text { preparation } \\
\text { of imple- } \\
\text { mentation }\end{array}$ & $\begin{array}{l}\text { All } 6 \text { hats in } \\
\text { preparation } \\
\text { of mainte- } \\
\text { nance }\end{array}$ \\
\hline $\begin{array}{l}\text { 3. Brain-storming } \\
\text { for synergy of } \\
\text { ideas / sug- } \\
\text { gestions }\end{array}$ & All 6 hats & White hat & $\begin{array}{l}\text { All } 6 \text { hats, red, } \\
\text { black, yellow, } \\
\text { green first of } \\
\text { all }\end{array}$ & $\begin{array}{l}\text { All } 6 \text { hats, } \\
\text { red, black, } \\
\text { yellow, } \\
\text { green first of } \\
\text { all }\end{array}$ & $\begin{array}{l}\text { All } 6 \text { hats in } \\
\text { preparation } \\
\text { of imple- } \\
\text { mentation }\end{array}$ & $\begin{array}{l}\text { All } 6 \text { hats in } \\
\text { preparation } \\
\text { of mainte- } \\
\text { nance }\end{array}$ \\
\hline $\begin{array}{l}\text { 4. Shared con- } \\
\text { clusions of the } \\
\text { circle }\end{array}$ & All 6 hats & White hat & $\begin{array}{l}\text { All } 6 \text { hats, red, } \\
\text { black, yellow, } \\
\text { green first of } \\
\text { all }\end{array}$ & $\begin{array}{l}\text { All } 6 \text { hats, } \\
\text { red, black, } \\
\text { yellow, } \\
\text { green first of } \\
\text { all }\end{array}$ & $\begin{array}{l}\text { All } 6 \text { hats in } \\
\text { preparation } \\
\text { of imple- } \\
\text { mentation }\end{array}$ & $\begin{array}{l}\text { All } 6 \text { hats in } \\
\text { preparation } \\
\text { of mainte- } \\
\text { nance }\end{array}$ \\
\hline
\end{tabular}

Table 2: Synergy of USOMID

\section{CONCLUSIONS}

The entire world, continents, countries, regions, and organizations tend to be governed by specialists of single professions, whose education for interdisciplinary creative cooperation is very rare, rather than by persons using systems theory and/or social responsibility. Democracy of over-voting does not replace creative cooperation. Ludwig von Bertalanffy (1978, p. VII) explicitly stated that he had created his General Systems Theory against over-specialization, i.e. to support interdisciplinary creative cooperation as the best way toward the necessary holism of approach and wholeness of outcomes of human activity. But he did not support his intention methodologically a lot. We did it with our Dialectical Systems Theory (DST). Peace can receive support from using it, so can development. Social responsibility is a next step, especially with support from methods of creative cooperation, e.g. USOMID and 'Six Thinking Hats'. Peace and development can result more easily than from one-sided fictitious democracy.

Narrow specialization is still necessary, but equally so is the other specialists' capacity: cooperation that helps humans prevent oversights and resulting failures, because it enables more holistic thinking/behavior. The role of the narrow specializations is so strong, though, that people hardly see that holistic thinking/behavior - enabled by interdisciplinary creative cooperation, backed by (ethics of) interdependence - makes specialization of any profession much more beneficial than any operation inside a specialization alone.

Nobody, whatever their profession, can live well without co-operation with people of other professions. De Bono's ' 6 Thinking Hats' support it, so does DST from the same period of time with our USOMID methodology of creative cooperation aimed at innovation. Both of them have been fruitfully applied all four decades since. 
A new support was recently offered: social responsibility (SR) with its all-linking concepts of (1) interdependence and (2) holistic approach is close to DST and liberal (rather than neo-liberal) economics (with competition in a free market with no monopoles), as authors understand the essence of the ISO 26000 on social responsibility (ISO, 2010) and European Union's (2011) support to it. Politicians and staff are supposed to be interested in social responsibility as a source of their benefit, but need knowledge and values to work on implementation of SR, perhaps with a specialized professional team support. The suggested findings should help humans find their way out from the current crisis, but in synergy; this crisis results from obsolete management and government style, including the issues of the world peace and development. (For new details see: Mulej et al, 2018; Šarotar Žižek and Mulej, editors, 2018; currently in press.)

\section{RÉFÉRENCES}

Grün, A., Zeitz, J. (2012): Bog, vest in denar. Pogovori med menihom in menedžerjem. Založba Družina, Ljubljana (God, Consciousness and Money. Debates between a monk and a manager)

Hrast, A., Mulej, M., et al., editors (2017): All 12 IRDO international conference SOCIAL RESPONSIBILITY AND CURRENT CHALLENGES 2006-2015. Proceedings. IRDO Institute for development of social responsibility, Maribor, Slovenia; see: www.irdo.si

Lebe, S. S. and Mulej, M., guest-editors and authors, with coauthors (2014): Social responsibility and holism in tourism. Kybernetes, vol. 43, iss. 3-4, 346-666

Mulej, M., R. Dyck, editors and coauthors, with coauthors (2014): Social responsibility beyond neoliberalism and charity. 4 volumes. Bentham Science, Shirjah, UAE

Mulej, M., Hrast, A, Dyck, R., guest-editors and authors, with coauthors (2014 and 2015): Social responsibility - a new socio-economic order. Systems Research and Behavioral Science, vol. 32, iss. 2, pp. 147-264

Mulej, M., Hrast, A., Ženko, Z., guest-editors and authors, with coauthors (2013): Social Responsibility - measures and measurement. Systems Practice and Action Research, vol. 26, iss. 6, 471-588

Mulej, M. and coauthors (2013): Dialectical Systems Thinking And The Law Of Requisite Holism Concerning Innovation. Emergent Publications', Litchfield Park, AZ, USA

Mulej, M., Merhar, V., Žakelj, V., Hrast, A., Čagran, B., editors (2016): Nehajte sovražiti svoje otroke in vnuke (Stop hating your children and grandchildren. In Slovene). IRDO and Kulturni center Maribor

Mulej, M., Merhar V., Žakelj, V., Hrast, A., Toplak, L., Slapnik, T., Ambrožič, B. (2018): Politična ekonomija družbeno odgovorne družbe. (Political Economy of a socially responsible society. (in Slovene) Kulturni center Maribor with IRDO

Šarotar Žižek, S., Mulej, M., editors (2018): Pametna proizvodnja (Smart Production. In Slovene). Two books. Kulturni center Maribor with IRDO 